\title{
POSISI PEREMPUAN DALAM TRADISI BUKA MEJA \\ (Studi Di Desa Cikeusal Lor, Kecamatan Ketanggungan, Kabupaten Brebes)
}

\author{
Oleh \\ Iman Fadhilah, S.HI., M.SI, \\ Dosen Universitas Wahid Hasyim Semarang \\ Email:iman_fadhilah@yahoo.co.id
}

\begin{abstract}
Abstrak
Berbicara soal budaya, memang sangat unik dan menarik; unik karena membahas satu kesatuan yang integral dalam suatu masyarakat, akan tetapi selalu ada kekhasan didalamnya, yang itu membedakan antara lokus yang satu dengan yang lain. Menarik karena bahasan budaya selalu memantik para ilmuwan untuk selalu mendalami budaya secara detail yang terkait dengan cita rasa dan kompleksitas masyarakat. Ada hal yang menarik terkait dengan Budaya buka meja yang dilakukan secara kontinyu di masyarakat Desa Cikeusal, Ketanggungan, Brebes. Pemilihan Desa Cikeusal, karena tradisi di Desa ini unik, berbeda dengan Desa-Desa pada umumnya di Kecamata Ketanggungan, Desa Cikeusal mengunakan bahasa sunda, padahal sekitarnya berbahasa Jawa, juga dengan tradisi perbatasan Sunda-Jawa. Ada relasi yang tidak imbang antara perempuan dan laki-laki dalam tradisi buka meja. Laki-laki menjadi subjek "yang berkuasa" atas perempuan,
\end{abstract}

Kata Kunci: Budaya, Tradisi Buka Meja, Laki-laki Perempuan.

\section{Pendahuluan}

Secara administrasi Desa Cikeusal adalah salah satu desa yang berada di wilayah Jawa Tengah, tetapi secara kultur condong ke wilayah Jawa Barat, misalnya bahasa dan budayanya. Desa Cikeusal terbagi menjadi dua, Cikeusal for (utara) dan kidul (selatan), sebelah utara Desa cikeusal berbatesan dengan Desa cisema, sebelah selatan Desa cikeusal berbatasan dengan Desa Pamedaran.

Dalam Tradisi buka meja, posisi perempuan dan laki-laki menjadi bagian yang tidak terpisahkan. Hanya saja, ada relasi yang tidak setara, bahkan relasi kuasa yang diskriminatif, laki-laki seolah menjadi "raja" ketika tradisi buka meja berlangsung .

Sekilas prosesi tradisi buka meja bisa digambarkan sebagai berikut, pertama, satu hari menjelang idul fitri, seluruh keluarga yang memiliki anak gadis perempuan, berbelanja untuk 
membeli makanan-makanan yang istimewa, snack, minuman, dan lain-lain, hal tersebut di peruntukan bagi tamu laki-laki yang nanti saat malam lebaran berkunjung ke rumah, bagi semua kalangan, tidak terkecuali, Pelajar atau Remaja masih belum bekerja dan lain-lain, harus mengikuti,tradisi ini, tanpa terkecuali, bagi tidak mengikuti, dianggap Khoriqul adah (menyalahi kebiasaan).

Dalam mengikuti tradisi ini, remaja yang laki-laki bisa berkunjung secara sendiri-sendiri atau berkelompok, mereka punya hak untuk memilih kepada siapa dan rumah mana dia berkunjung, padahal di setiap rumah yang memiliki gadis / perempuan, sudah di sediakan jamuan makan, mereka (remaja laki-laki) tinggal datang, menikmati hidangan, dan mereka bisa meninggalkan ketika tamu lain datang dengan seenaknya, pada titik ini, posisi perempuan seolah menjadi "tuan rumah", yang harus standby menerima tamu dengan sekian hidangan, dan remaja laki-laki ada juga yang meninggalkan amplop, secara variatif dan sesuai kemauan laki-laki.

Dengan fenomena di atas, maka penelitian mengangkat masalah inti: Analisis Posisi perempuan dalam Tradisi buka meja dilaksanakan di Desa Cikeusal Ketanggunagn Brebes. Dari masalah penelitian ini, peneliti merumuskan beberapa pertanyaan penelitian sebagai berikut:

Pertanyaan inti: bagaimana tradisi Buka Meja di Desa Cikeusal lor, merefleksikan relasi gender dan memosisikan perempuan?

Sub Pertanyaan:

Bagaimana Tradisi buka meja dilaksanakan di Desa Cikeusal Ketanggunagn Brebes?

Bagaimana kesejarahan Tradisi buka meja di Desa Cikeusal, sejauh mana masih mengikuti praktik yang lama atau telah berubah dan bagaimana masyarakat menjelaskannya ?

Bagaimana implikasi tradisi buka meja pada perempuan muda dan bagaimana mereka menanggapi praktik ini?

\section{Metode Penelitian}

Penelitian ini adalah penelitian lapangan yang metode pengumpulan datanya dilakukan dengan cara wawancara, observasi, dan dokumentasi. Sedang teknik analisisnya adalah kualitatif, dan untuk menginterpretasikannya digunakan pendekatan fenomelogis, dimana peneliti melakukan epoche, mengurung hasrat diri.untuk melakukan penilaian terlebih dahulu.

Lokasi yang menjadi obyek penelitian kali ini adalah Desa Cikeusal, Kec Ketanggungan, Kab Brebes. Metode penelitian yang digunakan menggunakan pola sebagai berikut Untuk 
mendapatkan data yang komprehensif tentang tradisi buka meja yang ada di Desa Cikeusal maka riset ini menggunakan metode kualitatif dengan pendekatan grounded theory.1 Dengan teori ini peneliti langsung terjun ke lapangan untuk membangun kedekatan (Raport) pada para informan. Data yang diperoleh dari informan yang terdiri dari tokoh masyarakat, Perangkat Desa, Tetua adat, dan masyarakat biasa yang merupakan data primer dalam riset ini. Dan data tersebut akan dilengkapi dngan dokumentasi data yang mendukung kelengkapan penelitian ini.

\section{Budaya dan Antropologi}

Kata Kebudayaan atau budaya adalah kata yang sering dikaitkan dengan Antropologi. Secara pasti, Antropologi tidak mempunyai hak eksklusif untuk menggunakan istilah ini. Seniman seperti penari atau pelukis dll juga memakai istilah ini atau diasosiasikan dengan istilah ini, bahkan pemerintah juga mempunyai departemen untuk ini. Konsep ini memang sangat sering digunakan oleh Antropologi dan telah tersebar kemasyarakat luas bahwa Antropologi bekerja atau meneliti apa yang sering diseb.ut dengan kebudayaan.

Seringnya istilah ini digunakan oleh Antropologi dalam pekerjaanpekerjaannya bukan berarti para ahli Antropolgi mempunyai pengertian yang sama tentang istilah tersebut. Seorang Ahli Antropologi yang mencoba mengumpulkan definisi yang pernah dibuat mengatakan ada sekitar 160 defenisi kebudayaan yang dibuat oleh para ahli Antropologi. Tetapi dari sekian banyak definisi tersebut ada suatu persetujuan bersama diantara para ahli Antropologi tentang arti dari istilah tersebut.

Salah satu definisi kebudayaan dalam Antropologi dibuat seorang ahli bernama Ralph Linton yang memberikan defenisi kebudayaan yang berbeda dengan pengertian kebudayaan dalam kehidupan sehari-hari: "Kebudayaan adalah seluruh cara kehidupan dari masyarakat dan tidak hanya mengenai sebagian tata cara hidup saja yang dianggap lebih tinggi dan lebih diinginkan". Jadi, kebudayaan menunjuk pada berbagai aspek kehidupan. Istilah ini meliputi caracara berlaku, kepercayaan-kepercayaan dan sikap-sikap, dan juga hasil dari kegiatan manusia yang khas untuk suatu masyarakat atau kelompok penduduk tertentu. Seperti semua konsepkonsep ilmiah, konsep kebudayaan berhubungan dengan beberapa aspek "di luar sana" yang hendak diteliti oleh seorang ilmuwan. Konsep-konsep kebudayaan yang dibuat membantu

\footnotetext{
${ }^{1}$ Strauss,Anselm \& Corbin,Juliet, 2009, Dasar-dasar Penelitian Kualitatif Tatalangkah dan teknik-teknik Teoritisasi Data, Yogyakarta: Pustaka Pelajar, hal 10
} 
peneliti dalam melakukan pekerjaannya sehingga ia tahu apa yang harus dipelajari. Salah satu hal yang diperhatikan dalam penelitian Antropologi adalah perbedaan dan persamaan mahluk manusia dengan mahluk bukan manusia seperti simpanse atau orang-utan yang secara fisik banyak mempunyai kesamaankesamaan. Bagaimana konsep kebudayaan membantu dalam membandingkan makhluk-makhluk ini? Isu yang sangat penting disini adalah kemamopuan belajar dari berbagai mahluk hidup. Lebah melakukan aktifitasnya hari demi hari, bulan demi bulan dan tahun demi tahun dalam bentuk yang sama. Setiap jenis lebah mempunyai pekerjaan yang khusus dan melakukan kegiatannya secara kontinyu tanpa memperdulikan perubahan lingkungan disekitarnya. Lebah pekerja terus sibuk mengumpulkan madu untuk koloninya. Tingkah laku ini sudah terprogram dalam gen mereka yang berubah secara sangat lambat dalam mengikuti perubahan lingkungan di sekitarnya.

Perubahan tingkah laku lebah akhirnya harus menunggu perubahan dalam gen nya. Hasilnya adalah tingkah-laku lebah menjadi tidak fleksibel. Berbeda dengan manusia, tingkah laku manusia sangat fleksibel. Hal ini terjadi karena kemampuan yang luar biasa dari manusia untuk belajar dari pengalamannya. Benar bahwa manusia tidak terlalu istimewa dalam belajar karena mahluk lainnya pun ada yang mampu belajar, tetapi kemampuan belajar dari manusia sangat luarbiasa dan hal lain yang juga sangat penting adalah kemampuannya untuk beradaptasi dengan apa yang telah dipelajari itu.

\section{Kebudayaan Diperoleh dari Belajar}

Kebudayaan yang dimiliki oleh manusia juga dimiliki dengan cara belajar. Dia tidak diturunkan secara bilogis atau pewarisan melalui unsur genetis. Hal ini perlu ditegaskan untuk membedakan perilaku manusia yang digerakan oleh kebudayaan dengan perilaku mahluk lain yang tingkah lakunya digerakan oleh insting. Ketika baru dilahirkan, semua tingkah laku manusia yang baru lahir tersebut digerakkan oleh insting dan naluri. Insting atau naluri ini tidak termasuk dalam kebudayaan, tetapi mempengaruhi kebudayaan. Contohnya adalah kebutuhan akan makan.

Makan adalah kebutuhan dasar yang tidak termasuk dalam kebudayaan. Tetapi bagaimana kebutuhan itu dipenuhi; apa yang dimakan, bagaimana cara memakan adalah bagian dari kebudayaan. Semua manusia perlu makan, tetapi kebudayaan yang berbeda dari kelompokkelompoknya menyebabkan manusia melakukan kegiatan dasar itu dengan cara yang 
berbeda. Contohnya adalah cara makan yang berlaku sekarang. Ada masa dulu orang makan hanya dengan menggunakan tangannya saja, langsung menyuapkan makanan kedalam mulutnya, tetapi cara tersebut perlahan lahan berubah, manusia mulai menggunakan alat yang sederhana dari kayu untuk menyendok dan menyuapkan makanannya dan sekarang alat tersebut dibuat dari banyak bahan. Begitu juga tempat dimana manusia itu makan. Dulu manusia makan disembarang tempat, tetapi sekarang ada tempat-tempat khusus dimana makanan itu dimakan. Hal ini semua terjadi karena manusia mempelajari atau mencontoh sesuatu yang dilakukan oleh generasi sebelumya atau lingkungan disekitarnya yang dianggap baik dan berguna dalam hidupnya. Sebaliknya kelakuan yang didorong oleh insting tidak dipelajari. Semut semut yang dikatakan bersifat sosial tidak dikatakan memiliki kebudayaan, walaupun mereka mempunyai tingkah-laku yang teratur. Mereka membagi pekerjaannya, membuat sarang dan mempunyai pasukan penyerbu yang semuanya dilakukan tanpa pernah diajari atau tanpa pernah meniru dari semut yang lain. Pola kelakuan seperti ini diwarisi secara genetis.

\section{Kebudayaan Milik Bersama}

Agar dapat dikatakan sebagai suatu kebudayaan, kebiasaan-kebiasaan seorang individu harus dimiliki bersama oleh suatu kelompok manusia. Para ahli Antropologi membatasi diri untuk berpendapat suatu kelompok mempunyai kebudayaan jika para warganya memiliki secara bersama sejumlah pola-pola berpikir dan berkelakuan yang sama yang didapat melalui proses belajar. Suatu kebudayaan dapat dirumuskan sebagai seperangkat kepercayaan, nilai-.nilai dan cara berlaku atau kebiasaan yang dipelajari dan yang dimiliki bersama oleh para warga dari suatu kelompok masyarakat. Pengertian masyarakat sendiri dalam Antropologi adalah sekelompok orang yang tinggal di suatu wilayah dan yang memakai suatu bahasa yang biasanya tidak dimengerti oleh penduduk tetangganya.

\section{Kebudayaan sebagai Pola}

Dalam setiap masyarakat, oleh para anggotanya dikembangkan sejumlah pola-pola budaya yang ideal dan pola-pola ini cenderung diperkuat dengan adanya pembatasan-pembatasan kebudayaan. Pola-pola kebudayaan yang ideal itu memuat hal-hal yang oleh sebagian besar dari masyarakat tersebut diakui sebagai kewajiban yang harus dilakukan dalam keadaan-keadaan tertentu. Pola-pola inilah yang sering disebut dengan norma-norma, Walaupun kita semua tahu 
bahwa tidak semua orang dalam kebudayaannya selalu berbuat seperti apa yang telah mereka dipahami atau dimengerti oleh mereka. Contohnya: tidak akan ada orang yang melarang seseorang di pasar Hamadi, Jayapura untuk berbelanja dengan menggunakan bahasa Polandia, akan tetapi dia tidak akan dilayani karena tidak ada yang memahaminya. Pembatasanpembatasan kebudayaan ini tidak berarti menghilangkan kepribadian seseorang dalam kebudayaannya.

Memang kadang-kadang pembatasan kebudayaaan tersebut menjadi tekanan-tekanan sosial yang mengatur tata-kehidupan yang berjalan dalam suatu kebudayaan, tetapi bukan berarti tekanan-tekanan sosial tersebut menghalangi individu-individu yang mempunyai pendirian bebas. Mereka yang mempunyai pendirian seperti ini akan tetap mempertahankan pendapatpendapat mereka, sekalipun mereka mendapat tentangan dari pendapat yang mayoritas. Kenyataan bahwa banyak kebudayaan dapat bertahan dan berkembang menunjukkan bahwa kebiasaan-kebiasaan yang dikembangkan oleh masyarakat pendukungnya disesuaikan dengan kebutuhan-kebutuhan tertentu dari lingkungannya. Ini terjadi sebagai suatu strategi dari kebudayaan untuk dapat terus bertahan, karena kalau sifat-sifat budaya tidak disesuaikan kepada beberapa keadaan tertentu, kemungkinan masyarakat untuk bertahan akan berkurang. Setiap adat yang meningkatkan ketahanan suatu masyarakat dalam lingkungan tertentu biasanya merupakan adat yang dapat disesuaikan, tetapi ini bukan berarti setiap ada mode yang baru atau sistim yang baru langsung diadopsi dan adat menyesuaikan diri dengan pembaruan itu. Karena dalam adatistiadat itu ada konsep yang dikenal dengan sistim nilai budaya yang merupakan konsep-konsep mengenai apa yang hidup dalam alam pikiran sebagian besar dari warga suatu kebudayaan tentang apa yang mereka anggap bernilai, berharga, dan penting dalam hidup, sehingga is memberi pedoman, arah serta orientasi kepada kehidupan warga masyarakat pendukung kebudayaan tersebut.

\section{Kebudayaan Bersifat Dinamis dan Adaptif}

Pada umumnya kebudayaan itu dikatakan bersifat adaptif, karena kebudayaan melengkapi manusia dengan cara-cara penyesuaian diri pada kebutuhan-kebutuhan fisiologis dari badan mereka, dan penyesuaian pada lingkungan yang bersifat fisik-geografis maupun pada lingkungan sosialnya. Banyak cara yang wajar dalam. hubungan tertentu pada suatu kelompok masyarakat memberi kesan janggal pada kelompok masyarakat yang lain, tetapi jika dipandang 
dari hubungan masyarakat tersebut dengan lingkungannya, baru hubungan tersebut bisa dipahami. Misalnya, orang akan heran kenapa ada pantangan-pantangan pergaulan seks pada masyarakat tertentu pada kaum ibu sesudah melahirkan anaknya sampai anak tersebut mencapai usia tertentu. Bagi orang di luar kebudayaan tersebut, pantangan tersebut susah dimengerti, tetapi bagi masrakat pendukung kebudayaan yang melakukan pantangan-pantangan seperti itu, hal tersebut mungkin suatu cara menyesuaikan diri pada lingkungan fisik dimana mereka berada. Mungkin daerah dimana mereka tinggal tidak terlalu mudah memenuhi kebutuhan makan mereka, sehingga sebagai strategi memberikan gizi yang cukup bagi anak bayi dibuatlah pantangan-pantangan tersebut. Hal ini nampaknya merupakan hal yang sepele tetapi sebenarnya merupakan suatu pencapaian luar biasa dari kelompok masyarakat tersebut untuk memahami lingkungannya dan berinteraksi dengan cara melakukan pantanganpantangan tersebut.

Pemahaman akan lingkungan seperti ini dan penyesuaian yang dilakukan oleh kebudayaan tersebut membutuhkan suatu pengamatan yang seksama dan dilakukan oleh beberapa generasi untuk sampai pada suatu kebijakan yaitu melakukan pantangan tadi. Begitu juga dengan penyesuaian kepada lingkungan sosial suatu masyarakat; bagi orang awam mungkin akan merasa adalah suatu hal yang tidak perlu untuk membangun kampung jauh diatas bukit atau kampung di atas air dan sebagainya, karena akan banyak sekali kesulitan-kesulitan praktis dalam memilih tempat-tempat seperti itu. Tetapi bila kita melihat mungkin pada hubungan-hubungan sosial yang terjaipli di daerah itu, akan didapat sejumlah alasan mengapa pilihan tersebut harus dilakukan. Mungkin mereka mendapat tekanan-tekanan sosial dari kelompok-kelompok masyarakat disekitarnya dalam bentuk yang ekstrim sehingga mereka harus mempertahankan diri dan salah satu cara terbaik dalam pilihan mereka adalah membangun kampung di puncak bukit.

Kebiasaan-kebiasaan yang ada dalam masyarakat tertentu merupakan cara penyesuaian masyarakat itu terhadap lingkungannya, akan tetapi cara penyesuaian tidak akan selalu sama. Kelompok masyarakat yang berlainan mungkin saja akan memilih cara-cara yang berbeda terhadap keadaan yang sama. Alasan mengapa masyarakat tersebut mengembangkan suatu jawaban terhadap suatu masalah dan bukan jawaban yang lain yang dapat dipilih tentu mempunyai sejumlah alasan dan argumen. Alasan-alasan ini sangat banyak dan bervariasi dan ini memerlukan suatu penelitian untuk menjelaskannya. Tetapi harus diingat juga bahwa masyarakat itu tidak harus selalu menyesuaikan diri pada suatu keadaan yang khusus. Sebab walaupun pada umumnya orang akan mengubah tingkah-laku mereka sebagai jawaban atau 
penyesuaian atas suatu keadaan yang baru sejalan dengan perkiraan hal itu akan berguna bagi mereka, hal itu tidak selalu terjadi. Malahan ada masyarakat yang dengan mengembangkan nilai budaya tertentu untuk menyesuaikan diri mereka malah mengurangi ketahanan masyarakatnya sendiri. Banyak kebudayaan yang punah karena hal-hal seperti ini. Mereka memakai kebiasaankebiasaan baru sebagai bentuk penyesuaian terhadap keadaan-keadaan baru yang masuk kedalam atau dihadapi kebudayaannya tetapi mereka tidak sadar bahwa kebiasaan-kebiasaan yang baru yang dibuat sebagai penyesuaian terhadap unsur-unsur baru yang masuk dari luar kebudayaannya malah merugikan mereka sendiri. Disinilah pentingnya filter atau penyaring budaya dalam suatu kelompok masyarakat.

Karena sekian banyak aturan, norma atau adat istiadat yang ada dan berlaku pada suatu kebudayaan bukanlah suatu hal yang baru saja dibuat atau dibuat dalam satu dua hari saja. Kebudayaan dengan sejumlah normanya itu merupakan suatu akumulasi dari 19pil pengamatan, hasil belajar dari pendukung kebudayaan tersebut terhadap lingkungannya selama beratus-ratus tahun dan dijalankan hingga sekarang karena terbukti telah dapat mempertahankan kehidupan masyarakat tersebut. Siapa saja dalam masyakarat yang melakukan filterasi atau penyaringan ini tergantung dari masyarakat itu sendiri. Kesadaran akan melakukan penyaringan ini juga tidak selalu sama pada setiap masyarakat dan hasilnya juga berbeda pada setiap.masyarakat. Akan terjadi pro-kontra antara berbagai elemen dalam masyarakat, perbedaan persepsi antara generasi tua dan muda, terpelajar dan yang kolot dan banyak lagi lainnya.

\section{Geografi Desa Cikeusal}

Desa Cikeusal merupakan bagian dari kecamatan Ketanggungan. Kecamatan Ketanggungan adalah sebuah kecamatan di Kabupaten Brebes, Jawa Tengah. Merupakan salah satu kecamatan yang agak unik yang ada di Kabupaten Brebes, yang hanya 9 Desa yang menggunakan Bahasa Jawa dari 21 Desa yang terdapat di kecamatan ini sedangkan sisanya menggunakan Bahasa Sunda Brebes. Letak wilayah Kecamatan Ketanggungan terletak di bagian tengah Kabupaten Brebes yang memanjang dari utara ke selatan pada dataran 17 meter diatas permukaan laut, namun demikian di wilayah Ketanggungan Selatan terdapat perbukitan di sekitar Desa Ciiikeusal dan Jemasih yang berbatasan dengan Kecamatan Bantarkawung dan Salem. Seperti daerah Brebes pada umumnya, bercuaca panas, dan adanya hembusan angin yang datang dari lereng Gunung Kumbang saat musim kemarau yang oleh masyarakat Brebes 
dinamakan angin kumbang ( jenis anginfohn ) yang hembusannya cukup dingin yang cocok untuk tanaman bawang merah. Terdapat pula dua sungai utama yaitu Sungai Babakan dan Sungai Buntiris, yang sangat berperan dalam irigasi pertanian, walaupun saat musim hujan terkadang aliran airn.ya cukup deras. Sebelah Utara ada Kecamatan Bulakamba, Kecamatan Tanjung. Sebelah Selatan Ada Kecamatan Salem, Kecamatan Bantarkawung. Sebelah Barat ada Kecamatan Banjarharjo, Kecamatan Kersana dan Sebelah Timur berbatasan dengan Kecamatan Larangan.

Dilihat dari komposisi penduduk, dapat dikatakan kalau penduduk Kecamatan Ketanggungan merupakan multikultural yang terdiri dari berbagai suku yaitu suku Jawa dan Sunda yang merupakan mayoritas serta terdapat pula komunitas Arab, Cina, Batak, Madura dan Minang / Padang. Sebagian masyarakat Kecamatan Ketanggungan bermatapencaharian sebagai petani, buruh tani, perkebunan, pedagang, pengrajin tempe / tahu, dan sektor jasa. Sektor pertanian yang menonjol adalah tanaman padi, palawija, bawang merah, cabe merah aneka jenis sayur mayur serta buah- buahan seperti mangga dan nangka.Terdapat pasar yang cukup ramai karena merupakakan tempat pertemuan antara pembeli yang berbelanja dengan para pedaganga dari warga di wilayah Ketanggungan bagian selatan sebagai penghasil sayur mayur yang cukup melimpah.

Dari aspek akses ekonomi dan transportasi Jalan yang melintasi Ketanggungan mempunyai posisi yang strategis karena merupakan jalan utama menuju akses ruas pantura / Pejagan dari arah Cirebon dan akses pintu tol Kanci - Pejagan terutama untuk kendaraan yang akan melintas dari Jakarta menuju jalur selatan ke arah Purwokerto atau Yogyakarta. Terdapat pula terminal dalam kota serta stasiun Kereta Api yang dikenal sebagai stasiun Ketanggungan Barat yang merupakan jalur KA Cirebon - Purwokerto

\section{Desa Cikeusal}

Desa Cikeusal terletak di sebelah selatan Ketanggungan. Di sebelah timur Desa cikeusal kidul adalah Desa sjpdang jaya dan Desa ciseureuh, sebelah selatannya Desa Pamedaran dan di sebelah baratnya Desa cikuya. Bahasa yang digunakan di daerah tersebut menggunakan bahasa Sunda Desa Cikeusal Lor berbatasan dengan Desa Cikeusal Kidul, dulunya satu kepemimpinan Kepala Desa, akan tetapi karena terlalu luas,Desa tersebut di pisah menjadi Desa Cikeusal Lor dan Kidul. Desa Cikeusal for memiliki beberapa dukuh diantaranya dukuh Campur, Dukuh Cisema, Babakan. Secara umum matapencaharian Masyarakat Desa Cikeusal Lor adalah Petani, 
dengan tingkat pendidikan yang memprihatinkan, hanya ada 1 Madrasah dan 2 Sekolah Dasar, dan belum memiliki Sekolah Menengah (SMP/MTs). Dengan demikian dapat dikatakan,warga Desa yang ingin mengenyam pendidikan setingkat SLTP harus ke kecamatan ketanggungan yang berjarak kira-kira $12 \mathrm{~km}$ dari Desa. Ada MTs (Madrasah Tsanawiyah) di Desa sebelah itupun masuknya sore, karena paginya di pakai untuk sekolah MI (madrasah ibtidaiyah) baru pada tahun 2006 memiliki sebagian lokasi gedung untuk sekolah pagi dan pada 2008 semua siswa bisa sekolah pagi, meskipun gurunya yang kerepotan, karena semuanya "nyabang", mendua, menjadi guru MI/SD sekaligus guru MTs.

Desa Cikeusal hanya memiliki satu TPQ (Taman Pendidikan al-Qur'an) yang bernama "Bustanul Muttaqien". MI nya bernama Miftahul Ulum, dengan satu mesjid "al-Muttaqin", SD 1 dan SD 2, itupun saat ini mau di integrasikan jadi 1 SD.

Tidak sedikit pula anak-anak yang sama sekali tidak mengenyam pendidikan walaupun hanya SD/MI, biasanya mereka dari kalangan keluarga yang miskin, si anak di suruh menggembala ternak, sapi atau kambing; atau kerbau. Selama kurang lebih 1 tahun, mereka angon ternak, maka baru akan mendapatkan imbalan. Atau setelah lulus SD/MI kebanyakan merantau ke jakarta dengan menjadi kuli bangunan, itu kalau anak laki-laki. Bagi anak perempuan biasanya lulus SD/MI di nikahkan atau merantau (kebanyakan ke Jakarta) dengan menjadi babu/pembantu.

Diantara buah pendidikan yang rendah itulah, Tingkat kenakalan remaja sangat tinggi, anak muda bermabuk-mabukan di luar rumah atau di jalan, itu di anggap biasa, bahkan tawuran anta9blok dalam satu Desa atau antar Desa menjadi hal yang sering sekali di temui. Bahkan, hampir setiap hari raya idul fitri atau lebaran menjadi agenda rutin untuk tawuran antar pemuda bahkan antar Desa.

\section{Perempuan di Desa Cikeusal}

Secara umum posisi perempuan di Masyarakat sunda, tidak terlalu berbeda dengan kondisi perempuan si masyarakat secara umum.

Dari aspek pendidikan, di Desa Cikeusal, Perempuan masih di anggap sebagai tidak memiliki masa depan yang cerah, sehingga sedikit sekali yang dapat mengenyam pendidikan tingkat tinggi. Sebagian besar hanya bersekolah SD/MI, ada beberapa yang sampai SLTP, yang sampai SMA/MA sangat sedikit, apalagi yang melanjutkan sampai perguruan tinggi, tidak lebih 
dari 5 orang. Secara populasi, perempuan di Desa Cikeusal memang lebih banyak jumlahnya, dari kurang lebih 16.000 penduduk, angka perempuan menunjukan separo lebih banyak dari pada angka laki-laki. Meski begitu, belum ada kesadaran untuk memposisikan perempuan dan lakilaki setara dengan perempuan. Anak perempuan lebih terampil di bawa ke sawah atau berkebun, mengurus sawah atau dapur, menjadi ibu rumah tangga.

Perempuan juga lah yang memadati pasar yang ada di Desa Cikeusal, jadi berbelanja itu "harus" perempuan, menjual dan berdagang juga kebanyakan yang di pasar perempuan, meski secara umum di berbagai daerah hampir sama, akan tetapi paling tidak ada satu hal yang membedakan.

\section{Posisi Perempuan dalam Beberapa tradisi di Desa cikeusal: \\ Tradisi sunat}

Sunat hanya berlaku bagi laki-laki, usianya variatif dari kelas 4 SD/MI sampai kelas 6 SD/MI, sampai tahun 1995an, anak laki-laki melakukan sunat di dukun sunat masih dengan menggunakan pisau. Ada juga mantri tetapi dengan jarak yang sangat jauh dari Desa, paling dekat di Kab Cirebon. Sehingga bagi mereka yang tidak mampu secara ekonomi, sunatnya cukup di pa Samad atau orang sana menyebutnya Ki Samad (satu-satunya dukun sunat waktu itu, mat ini sudah meninggal dunia). Bagi mereka yang mampu secara ekonomi, bis sunat ke manteri dengan notik ojeg atau di tandu ke daerah cirebon.

Bagi mereka yang akan di sunat, biasanya sejak subuh sudah bangun dan harus ngeem (berendam di kali) kurang lebih 1 jam, setelah itu di bawa kedukun sunat kemudian dilakukan sunat oleh dukun tersebut, setelahnya biasanya di masukan telur ayam kampung kedalam alat kelamin anak laki-laki tersebut, karena biasanya darah yang keluar cukup banyak, dan setelah itu dibawa pulang ke rumah, sesampainya di rumah, anak yang di sunat dusarankan langsung memegang payudara ibunya, kemudian di baringkan, setelah istirahat, agak siang, dia (anak yang telah disunat) sudah mulai keluar rumah dengan memakai bawahan sarung dan memakai tepes (kulit kelapa) sebagai batas antara alat kelamin dengan sarung agar tidak nempel. Kemudian dia mulai mencari tempat dimana ada perempuan atau gadis berkumpul. Aktifitas pertama yang dilakukan adalah mengejar gadis/perempuan muda untuk di pegang payudaranya, dan itu dilakukan setiap hari sampai is merasa sudah agak sembuh, biasanya masa kesembuhan dulu sampai 28 hari atau satu bulan. Keyakinan masyarakat sana, semakin banyak dia memegang payudara perempuan, maka semakin cepat sembuh hasil sunatnya tersebut, keyakinan yang aneh, 
akan tetapi di percaya masyarakat sebagai bagian yang harus dilaksanakan.

Sangat tidak rasional, akan tetapi apa mau dikata, masyarakat memegang teguh tradisi tersebut, perempuan seolah jadi obat saja bagi kesembuhan sunat si laki-laki, posisi perempuan sangat tidak terhormat, hanya di jadikan "tumbal" bagi laki-laki, di temukan, di kejar, lalu di pegang paudaranya, organ tubuh yang menjadi identitas kehormatan dan pantang untuk di lecehkan.

\section{Tradisi Nalian}

Nalian adalah salah satu proses "mengikat"dari pihak laki-laki kepada pihak perempuan, setelal?terjadi proses nalian, maka $75 \%$ perempuan sudah menjadi "hak" laki-laki, dia tidak boleh berinteraksi bebas dengan laki-laki lain, atau akrab dengan laki-laki lain. Pihak laki-laki memberikan kalung, cincin dan seperangkat pakaian untuk calon mitoha (mertua). Keluarga perempuan biasanya membatasi gerak anaknya karena sudah ada yang nali (membelenggu).

\section{Tradisi matok}

Matok adalah istilah bagi pihak laki-laki yang telah menjadikan pacarnya sebagai pilihan untuk masa mendatang, seorang laki-laki berhak matok terhadap seorang perempuan baik yang sudah dewasa ataupun yang masih di bawah umur. Syarat utama bisa matok lebih pada aspek ekonomi, bagi mereka yang secara strata sosial lebih tinggi atau lebih kaya, maka is berhak "mematok" terhadap siapapun yang dia kehendaki. Bagi tokoh tertentu atau tuan tanah, dan punya anak laki-laki, dia sangat punya otoritas untuk memilihkan pasangan bagi anakanya, sedini mungkin, bahkan sejak si perempuan itu masih SD/MI.

\section{Tradisi nganteran}

Tradisi nganteran dilaksanakan setelah prosesi dan resepsi pernikahan. Di sebut nganteran karena dalam tradisi ini, pihak perempuan harus nganteran kepada pihak keluarga lakilaki dan besan (saudara dari pihak laki-laki), atas permintaan pihak laki-laki yang kemudian di sepakati oleh pihak perempuan. Biasanya berkisar antara 30 sampai 40 orang. Besan Biasanya di bagi dalam dua kategori, sadulur deket (keluarga dekat) dan sadulur jauh, kalau untuk sadulur deket, jenis barang yang harus disediakan satu kasur di bungkus samak (tikar) dan karanghulu (bantal) dan sepuluh jenis makanan istimewa dalam rantang dan boboko, serta sepuluh jenis buah-buahan dan makanan ringan khas Desa seperti rangginang, cuhcur, papais dan lain-lain.

\section{Tradisi Buka Meja}




\section{Prosesi buka meja}

Kurang lebih satu atau dua hari menjelang malam idul fitri di setiap tahunnya, semua warga Desa cikeusal for yang memiliki anak gadis atau Perawan, atau janda, berbelanja makanan dan minuman yang lebih istimewa dari pada hari biasanya, tidak terkecuali, baik yang ekonominya biasa maupun miskin atau kaya. Sementara pihak laki-laki (bujang) yang masih sendiri, jejaka atau duda, mereka menyiapkan petasan / mercon; dengan cara membuat sendiri di rangkai (mercon rantai) atau di pisah, ada juga yang membeli, meski volumenya kecil. Bujang, jejaka atau duda juga menyiapkan amplop untuk nanti di isi uang sukarela.

Setelah berbuka puasa dan sholat maghrib, semua Bujang, jejaka atau duda, berkumpul sesuai genk (kelompok mereka masing-masing), ada yang 2 orang, 3 orang, atau 5, 7 orang sesuai banyak sedikitnya genk yang ada di Desa tersebut, misalnya ada blok bunut, blok renghas, BBS, Dukuh Campur, Lonly, dan lain-lain yang ada di Desa Tersebut, meskipun begitu, ada juga yang sendiri, sendiri, tapi itu sangat jarang. Pengelompokan ini juga biasanya terkait juga dengan status sosial, pelajar dengan pelajar, orang yang kaya dengan yang kaya, begitupun seterusnya.

Setelah mereka (Bujang, jejaka atau duda) berkumpul, kemudian mereka menentukan rute perjalanan yang akan di tempuh dari blok mana dulu, ke siapa dulu dan lain-lain (tentu dengan jalan kaki, masing-masing sudah membawa tas, ada juga yang tidak, tetapi sudah menyiapkan mercon sebanyak mungkin dengan ukuran yang variatif), perlu di ketahui juga bahwa tradisi buka meja ini dilakukan semalam suntuk sampai pagi.

Biasanya, rute awal adalah mereka (Bujang, jejaka atau duda), memilih perempuanperempuan yang cantik dulu, mereka data, kemudian memilih juga, yang biasanya banyak di kunjungi, pada tahun-tahun sebelumnya, selama dia (perempuan) tersebut belum menikah, yang berikutnya adalah yang makanannya enak-enak atau mewah-mewah, berikutnya saudara-saudara dari mereka dan sebagai penutup biasanya inti (perempuan yang mereka idamkan, bagi yang punya pacar, atau teman dekat atau yang dia incar), waktunya sudah mendekati subuh, atau pada waktu subuh, dan itu kunjungan spesial.

Ketika sudah memulai mengunjungi satu rumah dari salah satu perempuan yang sudah menjadi tujuan, sebelum masuk atau ketuk pintu, mereku membunyikan mercon terlebih dahulu dengan ukuran yang besar, biasanya minimal sebesar gelas minum standar.

Setelah mereka menyalakan atau membunyikan mercon, sampai suara mercon itu hilang atau habis tinggal sampahnya saja, barulah rombongan atau kelompok (Bujang, jejaka atau duda) 
ini masuk rumah secara bersama-sama. Setelah mereka memasuki rumah, kemudian si perempuan keluar dengan dandanan yang "paling cantik", karena dia harus menemani tamu sampai pagi, tentu butuh tenaga dan penampilan yang cukup ekstra. Setelah keluar, menyapa dengan senyum, tamu langsung di suguhi minuman yang khusus, kalau hari biasa, teh atau air putih biasa/aqua gelas, maka malam tersebut, minimal teh botol sosro, fanta dan lain-lain yang tentu menyedot biaya lumayan banyak.

Setelah menyajikan minuman, kemudian tamu di persilahkan menikmati hidangan, makanan, biasanya berupa jeruk, anggur, wafer dan lain-lain, yang bagi masyarakat Desa, itu jarang sekali di hidangkan, bahkan mungkin sekedar beli anggur saja atau jeruk, hanya saat mau lebaran itu saja.

Sambil menikmati hidangan, tamu dipersilahkan ngobrol, bercengkarama, merayu dan lain-lain semau mereka. Nah, pada saat inilah, para tamu biasanya seenaknya, karena mereka rombongan, kemudian mereka tidak jarang memperlakukan perempuan sebagai objek saja, di pegang, di cubit, duduknya di jepit duduknya dan lain-lain, dengan alasan nanti di kasih amplop saat mereka mau pulang

Batasan waktu ngobrol variatif, tidak ada ketentuan lama atau sebentar, yang membatasi adalah kalau di depan rumah sudah ada suara mercon berbunyi lagi atau pintu sudah di ketuk, berarti ada rombongan lain atau tamu lain yang akan berkunjung dan tamu yang ada di dalam rumah harus bergegas meninggalkan rumah tersebut, untuk berpindah ke tempat atau ke rumah perempuan yang lain.

Setelah menikmati hidangan, minum sudah, makan snack juga sudah, mereka menyelipkan satu amplop di bawah taplak meja, atau di letakan di sebelah hidangan makanan, ada jut yang dikasihkan langsung ke perempuan yang jadi tuan rumah, dengan jumlah semau dari rombongan tersebut, ada yang ngasih Rp.5000, 10.000, tergantung urunan mereka, ada juga yang kadang-kadang hanya 2000 atau 3.000 rupiah, suatu hal yang tidak imbang memang dengan apa yang suguhkan.

Kemudian mereka keluar rumah, dan masuklah rombongan yang lain ke perempuan tersebut, seperti proses awal dia(perempuan tersebut) harus menyapa dengan senyum, menjamu dengan baik, menemani ngobrol, dan seterusnya dan seterusnya seperti proses yang pertama tadi di jelaskan di atas. Setiap perempuan atau gadis di Desa Cikeusal, selama satu malam suntuk akan mengikuti siklus tersebut, menerima tamu, menemani ngobrol, ganti tamu, menemani 
ngobrol terus begitu.

Ketika di luar sudah ada tamu kembali, dan sudah membunyika mercon, ternyata tamud i dalam belum keluar rumah, maka calon tamu yang di luar membunyikan mercon kembali dan mengetuk pintu, tandanya mereka siap masuk, ternyata masih juga belum keluar rumah si tamu yang di dalam, maka biasanya hal ini yang menjadikan ribut (dalam bahasa sunda galulung), tawuran, biasanya sampai piring pecah, gelas, dan merusak perabotan rumah. (perlu di ketahui juga, tidak sedikit tamu yang biasanya datang dalam keadaan mabuk, sempoyongan, setengah sadar, karena malam tersebut seolah malam pesta miras bagi para remaja), dan ini sering sekali merugikan perempuan dan keluarga perempuan.

Ketika Tamu datang, baik kenal ataupun tidak kenal, si perempuan harus memberikan pelayanan prima, kalau tidak maka, tamu-tamu lain yang akan datang, akan di propokasi oleh tamu yang sebelumnya untuk tidak berkunjung, karena dianggap tidak ramah (sunda: teu sumeah, atawa teu garapyak)

Setiap rombongan, akan dipastikan mengunjungi para permpuan yang cantik, suguhannyya enak, dan satu Desa biasanya mereka acak,ketika sudah 2 atau tiga rumah saja, mereka sudah merasa kenyang, (sunda: seubeh), maka mereka tetap membawa makanan atau snack dari rumah yang dikunjungi dengan cara memasukan kedalam tas, yang pada saat berangkat di jadikan tas untuk tempat mercon.

Para rombongan selama semalam suntuk melakukan kunjungan, ngider, ke berbagai rumah yang ada gadisnya, sampai menjelang pagi/fajar. Bagi rumah yang memiliki dua atau tuga gadis, pihak keluarga tetap "membuka meja", akan tetapi saat tamu masuk, maka ada salah satu gadis yang keluar sambil menanyakan mau di temui atau di temani siapa?maka rombongan tersebut tinggal menyebut nama gadis yang mereka "maui", lalu, si gadis akan keluar dengan paras dan dandanan yang serba ',wah",

Saat menjelang fajar itulah, mereka mulai berpisah, bagi yang puya teman dekat, atau pacar, kabogoh, maka itulah kunjungan terakhir sebelum subuh, lelah, tidak lelah, si perempuan harus tetap menemani, tamunya, apalagi ini yang mereka tunggu.

Kalau ke perempuan yang tadi dikunjungi sebelumnya dia hanya memberi beberapa ribu saja, maka khusus untuk pacarnya atau teman dekatnya dia memberi sampai tujuh puluh lima ribu atau seratus ribu rupiah.

Dan setelah subuh tiba, si perempuan yang jadi pacarnya tadi harus "nganteran" dengan 
membawa makanan serba sepuluh, khas makanan Desa, sampai di bawa beberapa orang 3- 8 orang, makanan di gendong dan diantarkan ke rumah silaki-laki (pacarya tersebut), dan nanti disambut dengan mercon rantai yang sangat banyak dan "dipulang" dengan uang oleh pihak lakilaki.

Saat pagi tiba, akan kelihatanlah, rumah siapa yang paling banyak di kunjungi dari jumlah kertas bekas mercon yang di bunyikan, sampah kertas yang menumpuk di depan rumah sebagai simbol berapa banyak tamu yang datang, bagi perempuan yang di depan rumahnya hanya beberapa lembar kertas, bekas mercon saja yang ada, berarti tanda bahwa tamunya hanya sedikit yang datang, dan itu biasanya jadi cibiran.

\section{Pendapat tentang buka meja}

Tradisi buka meja bukan hal yang asing bagi masyarakat Desa Cikeusal lor, menurut Irwan Susandhi, Kepada Desa Cikeusal Lor, tradisi buka meja bukanlah hal yang baru, tetapi sudah turun temurun dari tetua Desa Cikeusal, "Kalau soal tahun dan tanggal pasOnya saya tidak juga hafal, kalau tidak salah, menurut cerita bapak saya, yang juga kebetulan kepala Desa Dulu,sejak adanya Desa ini, ya tradisi itu timbul meskipun dalam bentuk yang sangat sederhana". Demikian Pa Kades (Kepala Desa) Irwan menjelaskan.

Hal senada disampaikan oleh Tokoh Masyarakat Desa Cikeusal Bapak Nasrudin, menurutnya, sejarah buka meja ini sudah mendarah daging di masyarakat, karena merupakan warisan orang tua dahulu, "sudah ada sejak dulu" tegasnya.

Bagi masyarakat Desa Cikeusal, merupakan sebuah kebahagian apabila bisa mengikuti tradisi buka meja ini, khususnya bagi kalangan remaja, tradisi ini laksana pestanya anak muda di malam riaya (idul fitri). Salah satu gadis Desa Cikeusal, Saroh mengatakan, setiap perempuan seperti dirinya, sangat menunggu datangnya malam tradisi buka meja, baginya itu malam yang sangat membahagiaan sekaligus mendebarkan. Membahagiakan karena akan dikunjungi banyak pemuda dan pastinya akan rame sekali, sekaligus mendatangkan rejeki, mendebarkan, khawatir rumahnya akan sepi dari pemuda yang mengunjunginya.

Hal yang sama diungkapkan Anah, baginya mengikuti adat itu sangatlah senang, bagaimanapun seorang gadis, suka di puja, apalagi di kunjungi banyak orang sangatlah membanggakan, tegasnya. 
Meski begitu, ketika di wawancarai, Kades Irwan2 menjelaskan ada perubahan dalam pelaksanaan buka meja, baginya anak muda saat ini, kurang memahami esensi dan hakikat dari pelaksanaan tradisi tersebut, warisan budaya yang sejatinya agung dan memiliki nilai luhur, kurang begitu diresap'i oleh kaum muda. "sejarah tradisi ini yang anak muda jaman sekarang tidak banyak yang tahu", jelasnya. Hal senada disampaikan Tokoh Masyarakat, Bapak Nasrudin, 3 menurutnya ada pergeseran makna dalam tradisi buka meja, nilai kebersamaan, guyub dan silaturahim sebagai tujuan utama tradisi ini seringkali hilang menjadi ajang gengsi dan pamer kekayaan. "kami sangat sedih dengan ini, tapi ya bagaimana lagi, remaja jaman sekarang beda dengan yang dulu, ungkapnya.

Pelaksanaan tradisi buka meja memang harus ada persiapan khusus sebelumnya, pihak keluarga harus menyiapkan, jadi harus ada keterlibatan keluarga atau orang tua, pap, Irwan. Meski begitu, anak muda yang lebih menentukan terhadap jalan tidaknya tradisi itu, karena mereka yang melaksanakan.

Ketika diwawancarai, gadis, seperti Atun dan Anah, tidak menyangkal, bahwa tamu sangatlah semua anak muda sejak awal keberangkatan sudah menentukan arah tujuan bertamu, dan itu berdasarkan kesepakatan rombongan. Mereka juga mengakui kalau faktor kecantikan menjadi kunci bagi kunjungan tamu. Siapa saja yang akan bertamu tidak ada yang ditolak, meskipun tidak jarang dalam kondisi mabuk.4

Bagi kepala Desa, tradisi itu memang sudah rutin dengan caranya sendiri, masyarakat sering tidak mampu untuk mengelak dari hal-hal yang tidak diinginkan dalam pelaksanaannya, misalnya ada tamu-tamu yang mabuk dan berlaku tidak senonoh pun tuan rumah tidak berani mengusirnya, karena itu tamu mereka, dan akan berbuntut panjang jika tidak melayani dengan baik.

Menurut Bapak Nasrudin, itu termasuk yang berbeda dari pelaksanaan jaman dulu. Yang namanya silaturahim itu ya silaturahim, tidak sambil minumminuman air keras, ungkapnya. Jadi hakikat itu sudah hilang sekarang.

Saroh, Anah dan kebanyakan gadis di Cikeusal mengakui memang tugas mereka adalah melayani tamu, siapapun dan dalam kondisi apapun, .kadangkadang para perempuan tidak terlalu

\footnotetext{
${ }^{2}$ Wawancara dengan Bapak Irwan, 2 Januari 2015

${ }^{3}$ Wawancara dengan bapak Nasrudin, 2 Januari 2015

${ }^{4}$ Wawancara dengan Anah dan Atun, 4 Januari 2015
} 
peduli dengan keamanan mereka. Perilaku yang tidak baik dari para tamu mereka anggap sebagai cobaan dalam tradisi.

Ada hal yang membuat Kepala Desa dan Tokoh masyarakat berbeda pandangan, saat diwawancarai, kemungkinan tradisi buka meja ini juga di jadikan sebagai "aset" bagi para orang tua, aset ekonomi misalnya dengan bagaimana menDesain, agar penyajian begitu siap, dan anak yang masih dibawah usia, misal kelas 6 SD/MI, yang masih belum dewasa, di support untuk ikut tradisi ini, menurut mereka, itu bukan aset bagi orang tua, tetapi orang tua yang ingin mengenalkan anaknya kepada kaum muda atau masyarakat secara umum, tegas kepala Desa dan diamini tokoh masy9akat, Bapa Nasrudin.5

Meski disangkal, ini menjadi catatan, bahwa pelaksanaan tradisi ini, bukan hanya sekadar budaya saja, akan tetapi melibatkan berbagai aspek kehidupan.

\section{Posisi Perempuan Sunda; beberapa kajian}

Berbicara tentang karakteristik dan jati diri, seharusnya kita sadar bahwa perempuan Sunda kini adalah reflesi dari perempuan Sunda masa silam. Kata Gilles Deleuze, masa kini adalah citra aktual dan masa lalu adalah citra virtual, citra dalam cermin. Karena itu, aktualisasi diri perempuan Sunda masa kini bisa dilihat dari cermin masa lalunya. Tepatnya, perempuan Sunda masa kini teraktualisasikan oleh masa silam dan tertuliskan di dalamnya.

Kita tahu, budaya Sunda dalam tataran sejarahnya banyak mengalami persentuhan dengan dunia luar. Belum lagi alam yang memanjakan manusia Sunda, hutan yang hijau, tanah yang subur, air yang tak pernah berhenti mengalir. Tetapi memang, apabila ingin memahami bagaimana sesungguhnya perempuan Sunda itu, kita harus mencarinya dari masa lalu, secara khusus di antaranya dari nilai-nilai yang tersimpan dari kebenaran yang lisan dan tertulis atau, menurut Derrida, dari the active trace yang menghias konteks kekinian dan dari ketertidurannya pada masa lalu atau kenyataan inskripsi-inskripsi yang ada.

Ajip Rosidi pernah menulis bagaimana karakter perempuan Sunda itu dalam Manusia Sunda (1984). Dengan menggali nilai-nilai manusia Sunda dari tokoh-tokoh sastra yang tipikal, Ajip Rosidi menghadirkan sosok Purbasari Ayu Wangi dari tataran Sunda Kuno, duo wanoja luar biasa dari tataran Kamari: Dewi Pramanik-Ratna Suminar dan, dari tataran Kiwari: Raden Dewi Sartika. Ajatrohaedi menulis "Citra Wanita dalam Sastra Sunda" (1992) dalam sebuah jurnal sastra UI yang mengulas tokoh perempuan dalam karya sastra dan pengarang perempuan Sunda.

\footnotetext{
${ }^{5}$ Wawancara dengan Bapak Irwan dan Bapak Nasrudin, 2 Januari 2015
} 
Nina Herlina Lubis menulis "Wanita dalam Sejarah" dalam "Tradisi dan Transformasi Sejarah Sunda" (2000) yang menghadirkan citra perempuan Sunda dalam ruang kesejarahannya.

Kemudian, Jakob Sumardjo menafsirulang 10 pantun Sunda dalam Simbol-simbol Artefak Budaya Sunda (2003) dan menyoroti bagaimana pentingnya kedudukan perempuan Sunda kuno, hingga mereka menempati dunia atas, sedangkan laki-laki menempati dunia bawah, dan perempuan dan laki-laki itu bertemu di dunia tengah. Tentulah mereka semua menulis berdasarkan fakta yang ada, baik fakta pada tataran imajinatif yang memancarkan karakter perempuan Sunda pada tokoh yang melegenda, maupun fakta yang terekam oleh sej arah.

Berdasarkan penelusuran ilmiah yang ditulis oleh para ahli di atas, tergambar perempuan Sunda itu penuh dengan kekuatan dari dunia atas (kosmologi Sunda kuno), memiliki kecantikan yang seimbang (balance), pekerja keras (adaptasi dan kreativitas), dan ulet (etos kerja), sehingga mampu memimpin negara, memengaruhi arus politik, dan menciptakan sesuatu yang baru. Bila saya kemudian menyimpulkan bahwa perempuan Sunda masa kini adalah aktualisasi dari perempuan Sunda masa silam yang berkedudukan tinggi, dipuja, dan dianggap sebagai pusat kehidupan, pusat penciptaan, dan menjadi energi penceritaan, maka tidaklah heran bila perempuan Sunda masa kini masih menyiratkan hal-hal seperti itu: cantik, penuh kekuatan, tetapi juga pekerja keras yang ulet.

Maka sekarang, tidaklah mungkin perempuan Sunda tidak bisa bekerja dengan keras dan ulet, seharusnya peribahasa jadi pribumi di imahna sorangan ulah jati kasilih ku junti; berkeadilan politik; mengembangkan keadilan gender, khususnya untuk perempuan Sunda yang selama ini banyak dijadikan objek dan dieksploitasi karena kebutuhan ekonomi yang tidak adil; diterapkan dan menjadi kenyataan demi eksistensi etnis Sunda sendiri.

\section{Posisi Perempuan Sunda Dalam Tradisi Buka Meja}

Relasi Perempuan dan laki-laki sunda dalam tradisi buka meja memang patut menjadi perhatian serius. Apalagi terkait dengan keadilan gender. Satu hal yang sering menjadi pembicaraan setelah terlaksananya tradisi buka meja adalah prilaku tamu (laki-laki) yang sangat beragam, ada yang sopan, perhatian, perayu, tetapi tidak sedikit pula yang sering berlaku "kurang ajar". Saat berkunjung ke rumah seorang gadis, seringkali diantara pemuda yang datang memperlakukan tuan rumah layaknya tamu yang harus dilayani dan menjadi seperti seorang raja, mereka mulai mendekati si tuan rumah, duduknya menempel, memegang tangan, dan lain-lain, 
perlakuan ini yang tidak jarang gadis yang dikunjungi menjadi rikuh, serba salah, menolak tidak berani, diampun menjadi di lecehkan. Dalam karyanya "The Second Sex" Simone de Beauvoir menyatakan perempuan sebagai realitas biologis sekaligus tubuh scbagai sebuah konstruksi. Seks adalah sebuah konstruksi. Tubuh perempuan diatur dalam sebuah konstruksi.

Dampaknya, perempuan tidak memiliki otonomitas atas dirinya sendiri. Tidak jauh berbeda dengan apa yang disampaikan oleh Prof. Saparinah Sadli dalam tulisannya "sifat-sifat manusia yang dikehendaki oleh lingkungan sosialnya sejak seseorang masih usia dini. Termasuk peran seksual laki-laki dan perempuan.

Kalau di lihat dari beberapa pendapat di atas, maka sebenarnya prilaku para pemuda saat menghadapai tuan rumah dengan berbagai variasinya merupakan ujud dari lingkungannya. Lingkungan yang sangat mendeskriditkan perempuan, seolah perempuan menjadi hidangan saja dalam tradisi buka meja tersebut.

Belum lagi ada relasi kuasa (meminjam istilah Lewis Coser) yang tidak seimbang, bagaimana tidak, seorang atau kelompok pemuda berhak mutlak untuk menentukan kemana mereka berkunjung dengan seleranya, sehingga bagi perempuan yang secara fisik cantik, maka dialah yang akan memiliki tamu yang sangat banyak, hal itu diakui oleh para informan, khusunya mereka yang memiliki paras biasa. Pada sisi ini akan sangat jelas kelihatan, bagaimana tradisi tersebut tidak memiliki adil gender.

Posisi perempuan sangatlah tidak pada tempatnya, mereka harus berhias, menyiapakn hidangan dan setelah itu tamu "merengkuhnya" dengan seenaknya mereka, tidak ada hak untuk menolak di perlakukan semena-mena olah para pemuda (laki-laki), meski mereka terkadang dalam keadaan mabuk, berbicara sekenanya, tetapi apa boleh buat, bagi para gadis, mereka adalah tamu yang harus di servis dan di hormati. Sangat jelaslah, begitu tidak adilnya posisi perempuan dalam tradisi buka meja ini.

Subordinasi ini muncul karena sejak awal perempuan selalu di jadikan objek, adanya pembedaan hak dan kewajiban antara perempuan dan laki-laki dan adanya cara pandang masyarakat yang membenarkan perbedaan antara perempuan dan laki-laki itu sendiri. Subordinasi perempuan ini bermula dari pengekangan eksistensi perempuan dengan cara menginternalisasi perempuan dari diri mereka sendiri dan dari stereotof yang di ciptakan oleh masyarakat dan budaya.

Marry Wollestoncraft dalan, bukunya A Vindication of the rigth of Women menulis 
"salah satu ciri yang paling universal sekaligus mencolok adalah subordinasi wanita atas pria. Sekalipun saat ini banyak kemajuan-kemajuan politik dan budaya, akan tetapi masyarakat tetap menempatkan wanita sebagai subordinasi posisi pria. 6

Tidak jauh berbeda dengan apa yang ditulis oleh Elizabeth Cady Stanton dalam bukunya The Womens Byble. Menurutnya gambaran perempuan di masyarakat di buat oleh kaum patriarkhal dengan cara mencontoh laki-laki. Perempuan tidak dapat menjadi dirinya sendiri dan justru di haruskan tunduk kepada kaum laki-laki. Jika peremuan melihat dirinya sendiri, justri yang is lihat adalah perempuan yang sesuai dengan gambaran laki-laki.7

Dalam kasus tradisi buka meja misalnya, perempuan akan berhias dengan berbagai cara sebagaimana laki-laki di Desa cikeusal mempersepsikan tentang kecantikan, misalnya anggun, rambut panjang, atau sebaliknya pakaian minim, ketat biar kelihatan seksi, bukan karena pilihan sendiri, akan tetapi karena menyambut tamu yang harus sesuai dengan selera mereka, sebuah relasi yang menindas, karena perempuan menjadi "yang lain" dalam bahasanya Beauvoir.

Simon de Beauvoir8 misalnya menyebut laki-laki sebagai "diri" (the self) sementara perempuan sebaga "liyan" (The other). Laki-laki adalah sang subjek sementara perempuan adalah objek. Hal ini di dukung oleh pola patriarkhi dan budaya masyarakat yang pada akhirnya selalu memosisikan perempuan sebagai sub ordinat, kelas dua.

Betapa posisi perempuan sangat tidak strategis, diskriminatif kalau pola patriarkhi ini selalu menggelayuti masyarakat dalam prilaku keseharian dan budaya yang mengungkungnya.

Kate Millet dalam bukunya Sexual Politic menyebut pola dan ideologi patriarkhal membesar-besarkan perbedaan biologis antara laki-laki dan perempuan. Dan memastikan bahwa laki-laki selalu memiliki peran yang maskulin dan dominan. Sedanglik perempuan selalu memiliki peran yang feminim dan subordinat. 9

Apa yang di tulis Millet, menggambarkan Perempuan dalam tradisi buka meja, yang tidak hanya berdandan sebagaimana selera laki-laki, akan tetapi di "instruksikan" oleh keluarganya agar melayani tamu dengan prima, mulai dari sikap, tutur kata yang lembut dan karakter yang menyenangkan laki-laki, seperti mengambilkan makanan, minuman dan lain-lain.

Pada sisi lain, perempuan juga terbagi ke dalam beberapa bagian lagi, ada perempuan

\footnotetext{
${ }^{6}$ Rosemarie Putnam Tong, Feminist Thought, Yogyakarta : Jalasutra, 1998, hal 18

${ }^{7}$ Ibid

${ }^{8}$ Simonuvoir de Beauvoir, The Second Sex, Jakarta : Pustaka Primethea, 2003, hal 3

${ }^{9}$ Rosemarie Putnam Tong, Op cit, hal 73
} 
yang biasa, secara fisik dan ada perempuan yang cantik secara fisik, dalam tradisi buka meja ada perbedaan perlakuan, bagi mereka yang cantik akan mendapatkan perlakuan lebih, banyak di kunjungi dan jadi idola, bahkan tidak sedikit yang sampai bertengkar hanya karena soal gengsi bertamu pada "si Dia" yang cantik. Pada banyak kasus, tradisi ini sering ternodai karena terjadi hal-hal yang tidak diinginkan seperti tawuran, saling mencaci, dan lain-lain karena "berebut" untuk bertamu ke satu perempuan "idola".

Pas kiranya apa yang disampaikan Simon de Beauvoir bahwa "Tubuh lakilaki dapat memahami dirinya sendiri sementara tubuh perempuan tampak meninginkan signifikansi oleh dirinya sendiri, laki-laki mampu berfikir, tentang dirinya sendiri tanpa perempuan, sementara perempuan tidak dapat memikirkan dirinya tanpa laki-laki. Ia tak lebih dari apa yang dikatakan laki-laki, oleh karenanya, ia disebut seks, yang secara esensial datang kepada laki-laki sebagai makhluk seksual.10

Sangatlah jelas, bagaimana perempuan ingin menjadi perempuan ideal dengan cara memaknai apa yang di idealkan oleh laki-laki, cantik dengan ukuran laki-laki, anggun, feminim dan lain-lain.

\section{Kesimpulan}

Tradisi buka meja merupakan budaya turun menurun yang dilaksanakan di Desa Cikeusal lor. Budaya ini sebagai ajang silaturahmi antar pemudapemudi di Desa, dilaksanakan pada malam idul fitri di setiap tahunnya, Pihak perempuan menyajikan makanan dan minuman serba istimewa, sementara pihak laki-laki mengunjungi pihak perempuan secara bersamasama dengan membawa amplop berisi uang dan menyalakan mercon sebelum memasuki rumah.

Dalam perkembangannya, tradisi ini mengalami perubahan, dari segi tujuan sudah berbeda, tradisi buka meja menjadi ajang "gengsi sosial", bagi perempuan yang kaya sekaligus cantik maka penyajian untuk tamu sangatlah istimewa, begitupun para remaja datang dan memilih berkunjung kepada gadis yang cantik secara fisik.

Ada relasi yang tidak imbang antara perempuan dan laki-laki dalam tradisi buka meja. Laki-laki menjadi subjek "yang berkuasa" atas perempuan, dengan kekuasaannya, laki-laki berhak terhadap perempuan, seperti makanan yang telah di hidangkan, mulai ngobrol, memegang-megang dan lain-lain, sementara perempuan harus berdandan (bersolek) untuk menyambut tamu, melayani ngobrol, berlaku sopan, kesemuanpya dilakukan untuk

\footnotetext{
${ }^{10}$ Simon de Beauvoir, Op. Cit., hal ix
} 
menyenangkan tamu, perempuan menjadi objek, yang harus menyesuaikan standar kesukaan laki-laki.

Harus ada refleksi soal pola patriarkhi dan budaya masyarakat sunda yang cenderung diskriminatif ,ehingga mengembalikan tujuan buka meja menjadi ajang silaturahmi yang memberikan nilai positif bagi interaksi dan kekerabatan masyarakat. 


\section{DAFTAR PUSTAKA}

Alisyahbana, Sutan Takdir. 1988,. Kebudayaan Sebagai Perjuangan. Jakarta: PT Dian Rakyat. Anthropology", New York, Harper and Row Publishers,

Bachtiar, Harsya. 1994. Masyarakat Indonesia, dalam Majalah Ilmu-ilmu Sosial Di Indonesia jilid $x x$, No.4; Jakarta: Lembaga Ilmu Pengetahuan Indonesia.

Benedict, Ruth, 1980, Patterns of Culture. Boston: Houghton Mifflin Co. Berkomunikasi dengan Orang-Orang Berbeda Budaya. 2006. Bandung:Remaja

Boelaars, Y, 1984. Kepribadian Indonesia Modern, Suatu Peelitian Antropologi Budaya. Jakarta: PT Gramedia

Brahmana, Pertampilan S. 1997. Awal Pertumbuhan Kebudayaan Nasional Indonesia. Karya Tulis Pada Program Magister Kajian Budaya UNUD.

Deddy Mulyana dan Jalaluddin Rakhmat. Komunikasi Antar budaya: Panduan

Gadis Arivia, 2000, Ferninisme: Sebuah Kata Hati, Jakarta: Konipas, Geertz, Hildred. (1981). Aneka Budaya dan Komunitas di Indonesia.

Penerjemah : A Rahman Zainuddin. Jakarta : Yayasan Ilmu-Ilmu Sosial dan FIS - UI Geoffrey Parrinder, 2005, Teologi Seksual (terj), Yogyakarta: LKiS, Harris, Marvin, 1988, "Culture, People, Nature; An, Introduction to General

Harsojo,1999. Pengantar Antropologi. Bandung : CV Putra A Bardin. Ignas Kleden, 1987. Sikap Ilmiah dan Kritik Kebudayaan. Jakarta : LP3ES

Koentjaraningrat, 1996. Pengantar Ilmu Antropologi; Jakarta: Rineka Cipta. Koentjaraningrat. 1993, Masalah Kesukubangsaan dan Integrasi Nasional.

Jakarta : Penerbit Universitas Indonesia (UI- Press).

Kristi Poerwandari, 2011, Pendekatan Kualitatif untuk Penelitian Perilaku Manusia, Jakarta: LPSP3,

M. Quraish Shihab, 2010, Perempuan, Jakarta: Lentera Hati

M. Yasir Alimi, 2004.,Dekonstruksi Seksualitas Poskolonial, Yogyakarta: LkiS, Melalatoa, Junus M. ed., 1997. Sistem Budaya Indonesia, Jakarta: Kerjasama FISIP Universitas Indonesia dengan PT. Pamator Rosdakarya.

Rosemarie Putnam Tong, 1998, Feminist Thought, Yogyakarta: Jalasutra, Saparinah Sadli, 2010, Berbeda tetapi Setara, Jakarta: Kompas.

Simone De Beauvoir, 2003,Second Sex, Penerjemah: Toni B. Febriantono,

Nuraini Juliastuti, Pustaka Promethea, 
Strauss,Anselm \& Corbin,Juliet, 2009, Dasar-dasar Penelitian Kualitatif Tatalangkah dan teknik-teknik Teoritisasi Data, Yogyakarta: Pustaka Pelajar

\section{HASIL WAWANCARA:}

Wawancara dengan Kepala Desa Cikeusal Lor, Bapak Irwan S, tanggal 2 Januari 2015

Wawancara dengan tokoh masyarakat Desa Cikeusal Lor, Bapak Nasrudin, tanggal 2 Januari 2015

Wawancara dengan Anah (Gadis), tanggal 2 Januari 2015

Wawancara dengan Atun (Gadis), tanggal 4 Januari 2015 